\title{
SeED Shadow of SWIETENIA MaCrophylLA REMNANT TREES IN A MEXICAN RAINFOREST: IMPLICATIONS FOR FOREST MANAGEMENT
}

\author{
Raúl E. Alcalá 1 , Roxalma L. Alonso', and Gabriel Gutiérrez-Granados ${ }^{2,3}$ \\ 'Departamento de Ecología Evolutiva, Centro de Investigación en Biodiversidad y Conservación, \\ Universidad Autónoma de Morelos, Cuernavaca, Morelos, México \\ ${ }^{2}$ Laboratorio de Sistemas de Información Geográfica, Instituto de Biología, \\ Universidad Nacional Autónoma de México, México D.F., México \\ ${ }^{3}$ Corresponding author: gabgg@st.ib.unam.mx
}

\begin{abstract}
The understanding of processes affecting the regeneration and coexistence of tree species is of high concern in tropical landscapes disturbed by anthropogenic activities. In this study, we evaluated the seed shadow of eight small remnant Swietenia macrophylla trees to determine the possible consequences of selective logging on the first stages of natural regeneration. We expected to find a restricted dispersal ability and a marked loss of seeds due to biotic interactions. To test this, seed shadow per tree was quantified along four radial transects $(30 \times 1 \mathrm{~m})$ that provided $960-1 \mathrm{~m}^{2}$ squares for sampling. The wind direction and some tree characteristics as diameter at breast height and crown projection area were also considered as factors influencing seed shadow. We also scored the number of seeds predated or infested by fungi. In total, 540 seeds were found along transects. Around $86.1 \%$ of the 960 squares presented 0 or 1 seed, whereas $80 \%$ of the seeds were found within the first $20 \mathrm{~m}$ from the parent tree. The number of seeds lost through biotic interactions regressed on the distance to the parent tree fitted a quadratic model that explained $52.4 \%$ of the total variance. These results suggest that small remnant $S$. macrophylla trees display low dispersal ability caused by a restricted seed shadow and a high rate of seed damaged produced by biotic interactions. Therefore, removal of largest trees for trading could be negatively impacting the first stages of the natural regeneration of this high value species. Consequently, harvesting could threat the local permanence of $S$. macrophylla in these managed forests of the Mayan zone.
\end{abstract}

Key words: big-leaf mahogany, biotic interactions, harvesting, natural regeneration, seed dispersal, seed predation, selective logging, tropical forests management.

Resumen: Entender los procesos relacionados con la regeneración y coexistencia de árboles es un tema de gran relevancia en paisajes tropicales perturbados por actividades humanas. En este estudio, se evaluó la sombra de semillas en ocho árboles remanentes de Swietenia macrophylla para determinar las posibles consecuencias de la tala selectiva sobre los primeros estadíos de la regeneración natural de la especie. Se esperaba encontrar una dispersión limitada y una marcada pérdida de semillas debido a las interacciones bióticas. Para probar esto, la sombra de semillas por árbol fue evaluada en cuatro transectos radiales $(30 \times 1 \mathrm{~m})$ que redundaron en 960 cuadros de $1 \mathrm{~m}^{2}$ usados para el muestreo. También se consideró el efecto de la dirección del viento y las características de los árboles, así como el diámetro a la altura del pecho y el área de proyección de la copa, como posibles factores que influyen en la sombra de semillas. Además, se registró el número de semillas depredadas y las infectadas por hongos. En total se encontraron 540 semillas de S. macrophylla en los 960 cuadros usados para evaluar la sombra de semillas. Cerca de $86 \%$ de estos cuadros mostraron 0 o 1 semilla, mientras que $80 \%$ de las semillas se encontraron dentro de los primeros 20 m con respecto a los árboles madre. La regresión entre el número de semillas perdidas por interacciones bióticas y la distancia al árbol madre se ajustó a un modelo cuadrático que explicó el 52.4\% de la varianza total. Estos resultados sugieren que los árboles pequeños y remanentes de $S$. macrophylla muestran una baja capacidad de dispersión causada por una sombra de semillas limitada y una elevada tasa de pérdida de semillas por interacciones bióticas. Los resultados indican que la remoción de los árboles más grandes para su venta podría estar impactando negativamente sobre los primeros estadíos de la regeneración natural de esta especie de alto valor, y que consecuentemente, la extracción selectiva podría amenazar la permanencia local de la caoba en bosques manejados de la zona Maya.

Palabras clave: caoba de hoja ancha, corta de árboles, depredación de semillas, dispersión de semillas, extracción selectiva, interacciones bióticas, manejo de bosques tropicales, regeneración natural.

$\mathbf{T}$ he current dominant landscapes in tropical zones are those corresponding to disturbed forest by anthropic activities (Wright and Muller-Landau, 2006). Therefore, the understanding of key processes that affect natural regeneration is of great concern to the conservation and management of tropical forests. Seed dispersal is one of the first stages of 
natural regeneration and functions as a template for subsequent processes, such as predation, germination, competition, and growth, which in turn, may ultimately shape the density and spatial distribution of adult trees (Janzen, 1970; Clark and Clark, 1984; Chesson, 2000). Empiric studies have shown a characteristic limited seed dispersal in tropical trees (Hubbell et al., 1999; Dalling et al., 2002), which in addition experience with high levels of seed damage and seedling mortality. Then, human activities could impose additional effects on regeneration of tropical trees (Chapman et al., 2010; Gibson et al., 2011).

In particular, the selective logging, which is based on the extraction of target trees with the best characteristics for trading, is the commonest management activity in most tropical forests subjected to legal harvesting (Sist et al., 2003; Asner et al., 2005; Lacerda et al., 2008). In these landscapes, the study of processes associated with seed dispersal and recruitment are particularly relevant for commercial tree species because these are expected to be highly sensitive due to their loss of adult reproductive individuals (Lowe et al., 2005; Schupp et al., 2010; Magrach et al., 2011).

Species of Meliaceae have been logged intensively in Neotropics because of the high quality of their timber. As a result, they have undergone marked population declines throughout their entire geographical distribution (Grogan and Barreto, 2005; Gullison, 2009; Alcalá et al., 2014). Within Meliaceae, Swietenia macrophylla King is the most harvested species along its entire geographic range from Brazil to Mexico. The current distribution of S. macrophylla in Mexico is highly fragmented, although extensive areas sustaining natural populations of $S$. macrophylla are still present on the Yucatan peninsula, for example in the so-called Mayan zone located in Central Quintana Roo (Snook, 2003).

Within the Mayan zone forest management was largely unregulated since the late $19^{\text {th }}$ and for most of the $20^{\text {th }}$ century. Currently, the region and the human communities it supports are recognized for their efforts towards low impact, socially just, community based forestry management programs (Bray et al., 2003). Timber extraction depends on previous estimates of growth rates. Therefore, derived of the estimated growth rate of Swietenia macrophylla, the management program based on two important criterions, the 25 years cutting cycles and the minimum cutting diameter $(55 \mathrm{~cm})$ should guarantee the sustainability of this species (Bray et al., 2003). However, as a consequence of removal of largest trees, a high density of small remnant individuals is observed in managed forests (Gutiérrez-Granados and Dirzo, 2009). This fact is important considering that consequently, natural regeneration will depend almost exclusively on these small individuals (Gutiérrez-Granados, 2009). Although several studies have evaluated diverse components affecting natural regeneration in the Mayan zone (Snook and Negreros-Castillo, 2004; Snook et al., 2005;
Cámara-Cabrales and Kelty, 2009), none have explicitly focused on these trees, which after harvesting, represent the real regeneration source. Therefore, the aim of this study was to evaluate the seed shadow of small remnant $S$. macrophylla individuals in order to detect possible consequences of selective logging on the first stages of its natural regeneration. Specifically, we expected to find a restricted dispersal ability and a marked loss of seeds due to biotic interactions.

\section{Methods}

Study site. Field work was carried out in the ejido (communally owned land) X-Maben, located in the municipality of Felipe Carrillo Puerto (88 $08^{\circ}$ - $88^{\circ} 20^{\prime} \mathrm{W}, 19^{\circ} 00^{\prime}-20^{\circ}$ $00^{\prime} \mathrm{N}$ ), Quintana Roo, Mexico. Climate in the area is hot and humid with a mean temperature of $33^{\circ} \mathrm{C}$ and a precipitation of $1,300 \mathrm{~mm}$ (data generated from metereological station located in Carrillo Puerto, Quintana Roo). The predominant vegetation corresponds to humid tropical forest (Holdridge, 1967), with intermingled patches of savanna and flooded forest, depending on variations in the micro-topography and substrate (Gutiérrez-Granados et al., 2011).

Sampling design. The study was performed in a 50 ha stand subjected to a first cutting cycle in 1998. To characterize both, the pattern in which seeds are dispersed and the effect of biotic interactions on the final seed shadow, we selected eight reproductive individuals from a total of 67 previously mapped trees. The selected trees were those separated by a minimum distance of $100 \mathrm{~m}$ to avoid overlapping in seed shadow, according with the maximum dispersal distances reported for this species (Gullison et al., 1996). The development of fruits was recorded periodically from January to March.

Before, seeds were naturally detached from fruits, we set four radial $(30 \times 1 \mathrm{~m})$ transects per tree, initiating in the stem of each focal individual and oriented to the four Cardinal directions. The 32 transects provided a total of 960 squares $\left(1 \mathrm{~m}^{2}\right)$ utilized for sampling the seed shadow. Transects were surveyed for 2-10 days once all fruits were dehiscent. In each square, leaf litter was cautiously removed to expose the fallen seeds. A wooden stick $25 \mathrm{~cm}$ length was set in the ground immediately adjacent to each seed to mark its position. Then, seeds were counted and mapped in each sampling unit.

Two months later (June), all transects per tree were surveyed to locate the dispersed seeds, which were cautiously examined for possible indications of damage (i.e., holes, infected zones). In particular, the area containing the embryo was gently pressed to detect signs of putrefaction. After revision, all the previously mapped seeds were categorized as (1) removed, (2) consumed in situ, (3) infected by fungi or (4) viable (seeds with no apparent damage). 
Data analyses. Density of dispersed seeds.- As a first description of the seed shadow we characterized how seeds were distributed on the 960 sampling squares $\left(1 \mathrm{~m}^{2}\right)$. To do this, we estimated the probability of those squares presenting either $0,1,2, \ldots, N$ seeds. We also described the density of seeds through the average, median, and range values.

In addition, we investigated for possible inter-individual differences in the density of dispersed seeds. Because in this area dominant winds blow from west to east during the dispersal period (Cámara-Cabrales and Kelty, 2009), wind direction was also considered as a factor influencing seed shadow. The interaction term between both factors tested the generality of the wind effect among individual trees. Due to the discrete nature of the dependent variable (counts), we used a generalized linear model (GLM) with Poisson distribution and a log link function to perform analysis (Sokal and Rohlf, 1981).

Dispersal distance and tree size.- To determine the seed shadow of Swietenia macrophylla seeds around the parent trees, we first pooled per each individual tree, all seeds that were found in the four Cardinal directions for each unit of distance $(1 \mathrm{~m})$. Then, we pooled again the seeds across the eight trees for each unit of distance. Seed shadow was finally characterized by a GLM (general linear model with Poisson error distribution and a log link function) performed to evaluate the relationship between the number of seeds and the distance from the parent tree.

To evaluate effects of tree size and crown size on seed shadow we performed independent regression analyses. In particular, the effects of diameter at breast height (DBH) and crown projection area (CPA) on the largest dispersion distance were evaluated (Figure 1). According with Cámara-Cabrales and Kelty (2009), CPA was calculated using the mean-radius equation: $\mathrm{CPA}=\left[\Sigma\left(r^{2}\right) / 4\right] \times \pi$. In addition, we qualitatively evaluated a possible association between the crown shape and the seed shadow of each tree. A diagrammatic description of the crown shape was obtained by mapping the maximum length of the branches that were aligned to the four Cardinal directions.

Biotic interactions.- Finally, we evaluated the effect of biotic interactions on the shape of seed shadow. We performed three independent GLMs to evaluate the relationship between the number of seeds removed, the number of consumed in situ and/or infected by fungi, and the number of potentially viable seeds with distance from the parent tree.

\section{Results}

Density of dispersed seeds. In total, 540 seeds were found in the 960 squares utilized to describe the seed shadow of Swietenia macrophylla. From the total number of squares, $86.1 \%$ contained 0 or 1 seed, and the rest of squares had > 2 seeds. The average and median values were 0.5687 and 0.0 , respectively, whereas the range was $0-8$. The GLM
Table 1. Diameter at breast height (DBH), crown projection area (CPA) and largest seed dispersal distances recorded in eight small remnant Swietenia macrophylla trees in the Mayan Zone of Quintana Roo.

\begin{tabular}{lccc}
\hline Tree & DBH $(\mathrm{cm})$ & $\mathrm{CPA}\left(\mathrm{m}^{2}\right)$ & $\begin{array}{c}\text { Largest dispersal } \\
\text { distance }(\mathrm{m})\end{array}$ \\
\hline 1 & 46.2 & 127.2 & 30 \\
2 & 47.4 & 90.6 & 30 \\
3 & 46.5 & 76.7 & 29 \\
4 & 35.7 & 48.0 & 29 \\
5 & 44.6 & 72.5 & 30 \\
6 & 42.0 & 40.4 & 18 \\
7 & 48.1 & 107.1 & 28 \\
8 & 39.5 & 43.5 & 21 \\
\hline
\end{tabular}

performed on density of seeds showed that all three effects were significant, with the highest effect being tree identity, followed by transect orientation and the interaction term, respectively (Table 2). The inspection of the relationship between deviance with degrees of freedom indicated absence of overdispersion. Density of seeds ranged from 0.19 to 1.0 among trees. Average density between transects ranged from 0.41 to 0.8 , with the West-orientated transect presenting the highest density (Figure 1A). The significance of the interaction term indicated that the effect of transect orientation was not constant among trees (Table 2, Figure 1). For example, only two out of eight trees (individuals 4 and 5) clearly dispersed more seeds toward the West-transect. Although DBH ranged from 35.7 to $48.1 \mathrm{~cm}$, and CPA varied between 40.4 and $127.2 \mathrm{~m}^{2}$ (Table 1), the individual differences in density of dispersed seeds were not explained by these size variables (data not shown). The inter-transect differences seem not to be related with crown shape, as no clear deviations of crown toward West direction were detected for trees 4 and 5 (Figure 1B).

Dispersal distance and tree size. The regression analysis performed to evaluate the seed shadow showed a negative relationship (slope $=-0.04$ ) between the number of dispersed seeds with the distance to parent trees (Wald statistic $=65.36, \mathrm{df}=1, P<0.0001$; Figure 2). In this model no evidence of overdispersion was detected. Of the total seeds found, $46 \%$ and $80 \%$, were located within the first $10 \mathrm{~m}$ and $20 \mathrm{~m}$ from the parent tree, respectively.

Table 2. General Linear Model with Poisson distribution and a log link function including the effect of tree identity, transect orientation, and the interaction between these factors on the number of seeds dispersed in small remnant individuals of Swietenia macrophylla.

\begin{tabular}{lccc}
\hline Effect & Wald statistic & df & $P$ \\
\hline Tree $(\mathrm{T})$ & 251.74 & 7 & $<0.0001$ \\
Orientation $(\mathrm{O})$ & 40.52 & 3 & 0.0017 \\
$\mathrm{~T} * \mathrm{O}$ & 15.09 & 21 & 0.0260 \\
\hline
\end{tabular}


A
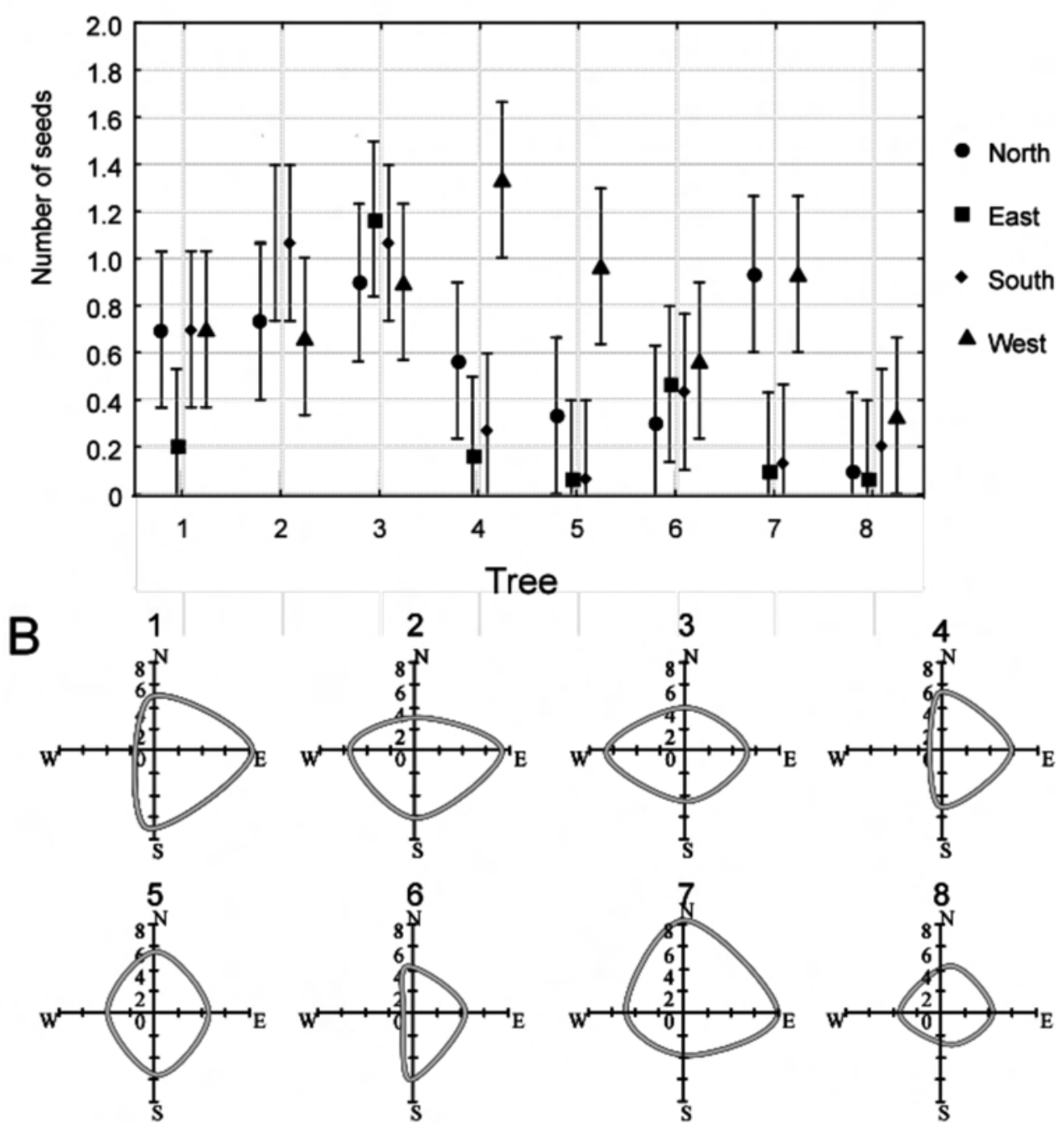

Figure 1. (A) Shape of the crowns of the eight small remnant individuals of Swietenia macrophylla and mean ( \pm 1 SD) of the number of seeds scored across the (B) four transects (orientation) for eight small remnant trees of S. macrophylla.

In contrast with the observed for density of dispersed seeds, the maximum dispersal distance was correlated with the variation in the CPA $(\beta=0.7561, P=0.03)$. The trees with CPA $<70 \mathrm{~m}^{2}$ tended to disperse seeds around $20 \mathrm{~m}$ from the parent trees, whereas individuals with CPA $>75 \mathrm{~m}^{2}$ dispersed seeds up to $30 \mathrm{~m}$ (Figure 3 ). No association between maximum dispersal distance and DBH was found (results not shown).

Biotic Interactions. In the census performed two months after seed dispersal, $72 \%$ of the total dispersed seeds were found. The remaining $28 \%$ was interpreted as removed seeds. Most of seeds that were found $(82 \%)$, corresponded to seeds that had undergone consumption and/or attack by fungi. Only $17 \%$ were considered to be intact and representing potentially viable seeds.
The scattering pattern of the number of seeds lost by biotic interactions against distance from parent tree described a parabolic curve (Figure 4A), therefore a quadratic model was used, in which both the simple ( $\beta=0.12$, Wald statistic $=17.11, \mathrm{df}=1, P=0.00003)$ and the quadratic effect were significant $\left(\beta^{2}=-0.005\right.$, Wald statistic $=29.23, \mathrm{df}=1, P<$ 0.00001 ). Seeds located around the first $10-15 \mathrm{~m}$ faced the highest risk to be attacked (Figure 4A). The number of removed seeds also showed a curved scattering pattern, however, in this case, only a linear relationship was detected $(\beta=$ -0.056 , Wald statistic $=8.31, \mathrm{df}=1, P<0.0031$; Figure 4B). In both regression models no evidence of overdispersion was found. In contrast, the number of viable seeds was not associated with distance from parent trees (data not shown, Figure 4C). 


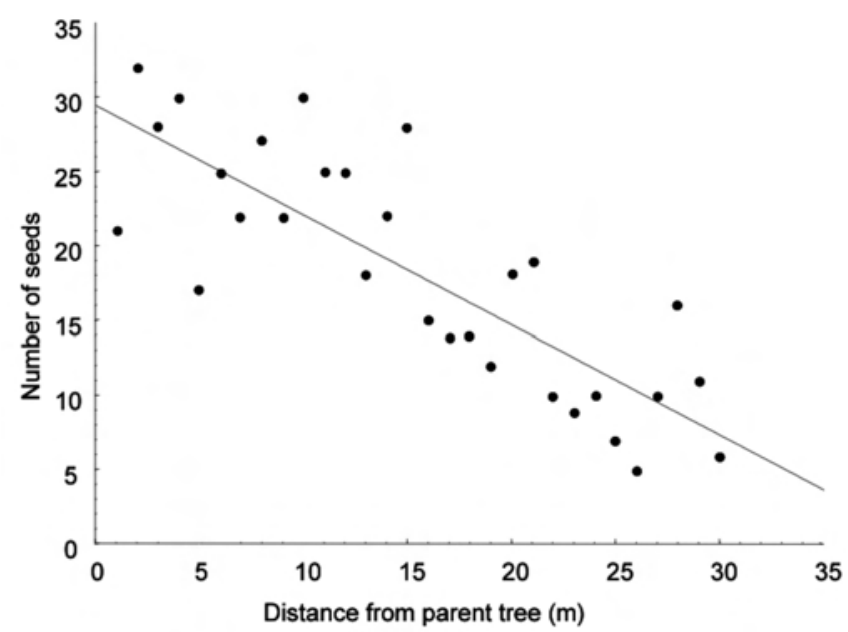

Figure 2. Relationship between the number of dispersed seeds and distance in remnant trees of Swietenia macrophylla.

\section{Discussion}

Swietenia macrophylla is the natural resource that most contributes to the well-being for people inhabiting the Mayan zone, therefore its trading should assure the future local existence of this species. Accordingly with the current polycyclic management program (Snook, 2003), largest trees were logged 25 years ago. As a result, the information about the ecological consequences derived of the first cutting cycle turns critical before the second cycle could be proximately implemented. Some of the studies documenting components of tree reproduction and even seed shadow in this zone have included trees from a size category that is not the most frequent (Snook et al., 2005; Cámara-Cabrales and Kelty, 2009). The results derived of our study documenting the seed shadow of remnant trees are particularly important for the management of $S$. macrophylla because selective logging in the Mayan

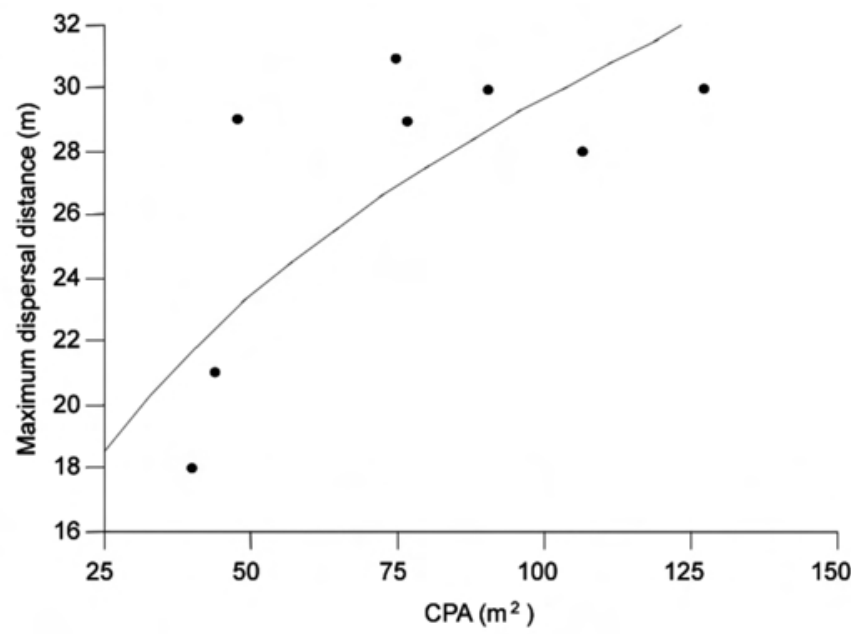

Figure 3. Effect of the variation of the crown projection area on the maximum dispersal distance of the seeds of Swietenia macrophylla.
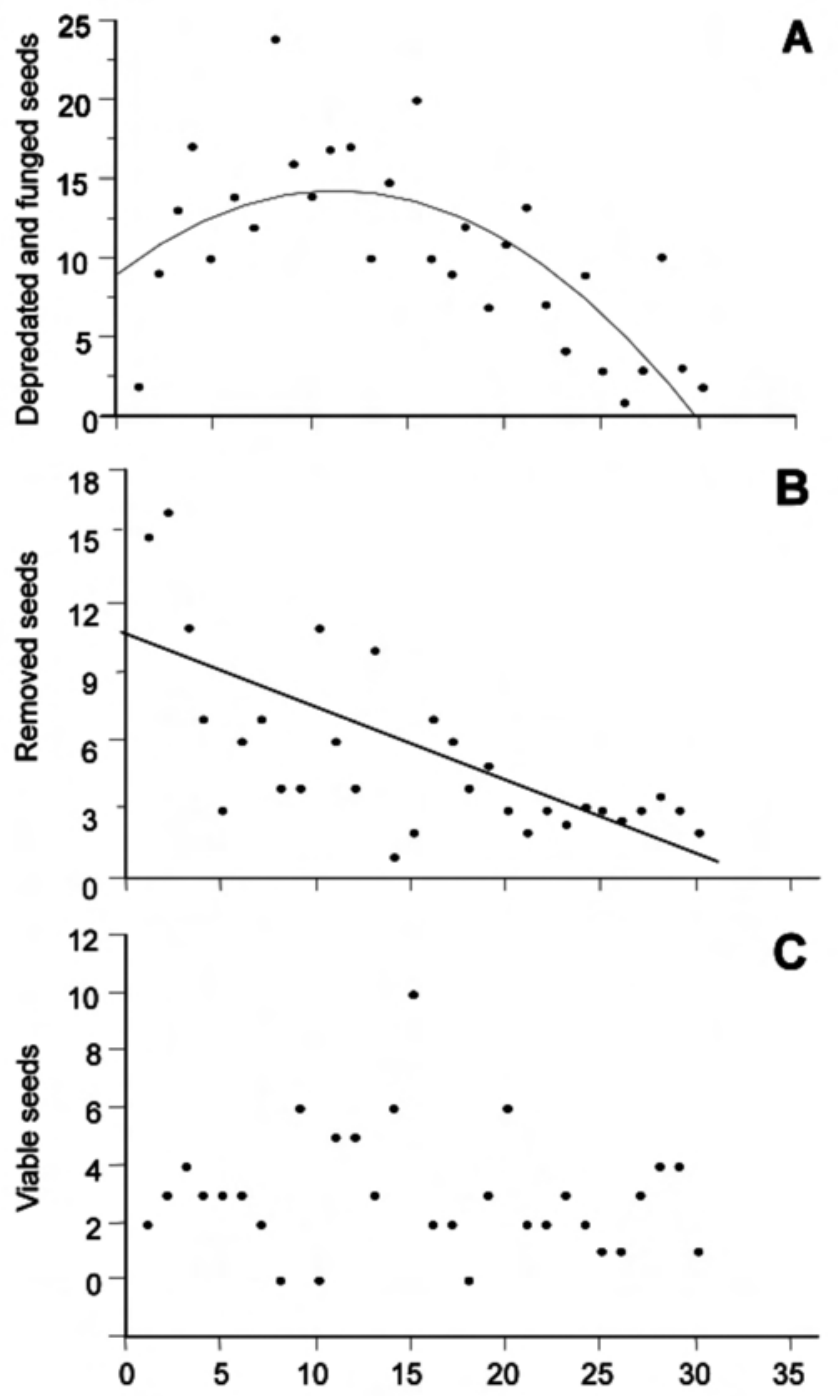

Figure 4. Relationship between the number of attacked (A), removed (B) and viable seeds $(C)$ and distance in small remnant trees of Swietenia macrophylla.

zone changes the population size structure causing that small trees occur at higher densities (Patiño, 1997; Santos et al., 2005; Gutiérrez-Granados et al., 2011).

First, our results indicate a lower seed production in the small trees of Swietenia macrophylla that remain after selective logging with regard to the reported in other studies (Medjibe and Hall, 2002; Grogan and Galvão, 2006; Medjibe et al., 2011). In this study, the eight trees showed a DAP that ranged from 35.7 to $48.1 \mathrm{~cm}$ and produced only between 4 to 23 fruits. This number of fruit corresponds to the observed in other studies for trees of the smallest size class, as fruit production positively correlates with tree size (Plumptre, 1995; Snook et al., 2005). Thus, small size of trees could explain the overall low density scored in this study. Although the effect of transect orientation was significant, this was not related to wind direction, as more seeds 
should have been registered toward the East direction. We suppose that the lack of effect of wind direction could also be attributable to the small size of individuals. Interestingly, inter-transect differences were not also related to the variation in crown shape. Probably, the description of crown shape forced on the four Cardinal directions as done in this study, could constrain its natural variation. Alternatively, our description of crow shape could have underestimated the variation along the height of the crown.

Second, we reported a restricted seed dispersal, as nearly $50 \%$ of total seeds fall within a distance of only $10 \mathrm{~m}$ from the parent tree, whereas other studies have reported higher dispersal distances from the parent tree (Gullison et al., 1996; Grogan and Galvão, 2006; Cámara-Cabrales and Kelty, 2009), even in other areas within the Mayan zone (Cámara-Cabrales and Kelty, 2009). However, those studies described seed shadow in larger trees. In contrast, our study focused on those trees left after the first cutting cycle and that predominantly represent the main source for seed dispersal. In addition, we detected that the maximum dispersal distance was positively correlated with the variation in CPA. Trees with CPA higher than $70 \mathrm{~m}^{2}$ increased maximum dispersal distance by around $10 \mathrm{~m}$. Therefore, in the study area, CPA instead of DAP should be considered as a key factor to estimate dispersal distance.

Third, ecological factors such as seed predation and secondary dispersion tend to determine the final shape of seed shadow (Roberts and Heithaus, 1986; Böhning-Gaese et al., 1999; Vander Wall et al., 2005; Magrach et al., 2011). The Janzen-Connell model (Janzen, 1970; Connell, 1971) states that host-specific seed predators, or seedling herbivores and pathogens, may have a disproportionately large negative effect on progeny close to parent trees. Our results clearly indicate that the limited seed dispersal displayed by remnant trees is associated with a high risk of predation or infection by pathogens. Based on the quadratic regression, the probability of attack peaked at a distance of 10-15 $\mathrm{m}$ from the parent tree. Although we recorded around $17 \%$ of big-leaf mahogany seeds as viable, the generalized absence of seedlings and saplings around the adult trees suggests that currently there is no natural regeneration (Gutiérrez-Granados, 2009). We proposed that the theoretical derivation of the JanzenConnell model could translate into the applied ecological recommendation of assuring the seed/seedling establishment far from parent trees or any conspecific adult. This practice will allow increasing the establishment probabilities.

Under the current scenario of human-induced disturbance, knowledge about secondary forests will be an essential part of managed forests (Putz and Redford, 2010). Thus, information as the presented here is important considering that these managed forests necessarily have smaller trees than before logging. Studies addressing the impact of selective logging should focus on the ecology of small remnant trees as they represent the real source of seeds. In addition, chan- ges in distance-dependence processes need to be taken into account when an artificial regeneration based on seeds/seedlings is promoted. In particular, a complete understanding of the ecology of Swietenia macrophylla along its distribution range including different conservation conditions, could help to maintain healthy populations or to support restoration programs in areas where the species has been locally extirpated, in benefit for the inhabitants of these areas.

\section{Acknowledgements}

The authors thank Luis M. Castro and Marlene de la Cruz for their help with the field work, and acknowledge the support provided by Ing. Victoria Santos and Rosa Ledezma and the Organización de Ejidos Productores Forestales de la Zona Maya, S.C. We also thank the comments and suggestions made by two reviewers that highly improved the manuscript. The study was funded by the Comisión Nacional para el Uso y Manejo de la Biodiversidad (CONABIO) throughout project FQ006.

\section{Literature cited}

Alcalá R.E., Salazar H., Gutiérrez-Granados G. and Snook L.K. 2014. Genetic structure and genetic diversity of Swietenia macrophylla (Meliaceae): Implications for sustainable forest management in Mexico. Journal of Tropical Forest Science 26:142-152.

Asner G.P., Knapp D.E., Broadbent E.N., Oliveira P.J., Keller M. and Silva J.N. 2005. Selective logging in the Brazilian Amazon. Science 310:480-482.

Böhning-Gaese K., Gaese B.H. and Rabemanantsoa S.B. 1999. Importance of primary and secondary seed dispersal in the malagasy tree Commiphora guillaumini. Ecology 80:821-832.

Bray D.B., Merino-Pérez L., Negreros-Castillo P., Segura-Warnholtz G., Torres-Rojo J.M. and Vester H.F.M. 2003. Mexico's community-managed forests as a global model for sustainable landscapes. Conservation Biology 17:672-677.

Cámara-Cabrales L. and Kelty M.J. 2009. Seed dispersal of bigleaf mahogany (Swietenia macrophylla) and its role in natural forest management in the Yucatán Peninsula, Mexico. Journal of Tropical Forest Science 21:235-245.

Clark D.A. and Clark D.B. 1984. Spacing dynamics of a tropical rain forest tree: Evaluation of the Janzen-Connell model. The American Naturalist 124:769-788.

Connell J.H. 1971. On the role of natural enemies in preventing competitive exclusion in some marine animals and in forest trees. In: den Boer P.J. and Gradwell G.R. Eds. Dynamics of Populations. Proceedings of the Advanced Study Institute on "Dynamics of Numbers in Populations, pp. 298-313, Center of Agricultural Publishing and Documentation, Wageningen.

Chapman C.A., Chapman L.J., Jacob A.L., Rothman J.M., Omeja P., Reyna-Hurtado R., Hartter J. and Lawes M.J. 2010. Tropical tree community shifts: implications for wildlife conservation. Biological Conservation 143:366-374.

Chesson P. 2000. Mechanisms of maintenance of species diversity. Annual Review of Ecology and Systematics 31:343-366. 
Dalling J.W., Muller-Landau H.C., Wright S.J. and Hubbell S.P. 2002. Role of dispersal in the recruitment limitation of neotropical pioneer species. Journal of Ecology 90:714-727.

Gibson L., Lee T.M., Koh L.P., Brook B.W., Gardner T.A., Barlow J., Peres C.A., Bradshaw C.J.A., Laurance W.F., Lovejoy T.E and Sodhi N.S. 2011. Primary forests are irreplaceable for sustaining tropical biodiversity. Nature 478:378-381.

Grogan J. and Barreto P. 2005. Big-leaf mahogany on CITES Appendix II: Big challenge, big opportunity. Conservation Biology 19:973-976.

Grogan J. and Galvão J. 2006. Factors limiting post-logging seedling regeneration by big-leaf mahogany (Swietenia macrophylla) in Southeastern Amazonia, Brazil, and implications for sustainable management. Biotropica 38:219-228.

Gullison R.E. 2009. Will bigleaf mahogany be conserved through sustainable use? In: Milner-Gulland E.J. and Mace R. Eds. Conservation of Biological Resources. pp. 193-205, Blackwell Science Ltd, Oxford.

Gullison R.E., Panfil S.N., Strouse J.J. and Hubbell S.P. 1996. Ecology and management of mahogany (Swietenia macrophylla King) in the Chimanes Forest, Beni, Bolivia. Botanical Journal of the Linnean Society 122:9-34.

Gutiérrez-Granados G. 2009. Efectos directos e indirectos de la extracción forestal sobre la diversidad vegetal y la interacción mamífero-planta en la selva Maya de Quintana Roo. Ph.D. Dissertation, Instituto de Ecología, Universidad Nacional Autonoma de México, Mexico, D.F. 200 pp.

Gutiérrez-Granados G. and Dirzo R. 2009. Extracción de madera en la zona maya de Quintana Roo: un análisis de tres ejidos sugiere un manejo forestal sustentable. In: Dirzo R., González R. and March I.J. Eds. Capital Natural de México Vol. II. Estado de Conservación y Tendencias de Cambio, pp. 252-255, Comisión Nacional para el Conocimiento y Uso de la Biodiversidad, México, D.F.

Gutiérrez-Granados G., Pérez-Salicrup D.R. and Dirzo R. 2011. Differential diameter-size effects of forest management on tree species richness and community structure: implications for conservation. Biodiversity and Conservation 20:1571-1585.

Holdridge L.R. 1967. Life Zone Ecology. Tropical Science Center, San José.

Hubbell S.P., Foster R.B., O’Brien S.T., Harms K.E., Condit R., Wechsler B., Wright S.J. and Loo de Lao S. 1999. Light gap disturbances, recruitment limitation, and tree diversity in a Neotropical forest. Science 283:554-557.

Janzen D.H. 1970. Herbivores and the number of tree species in tropical forests. The American Naturalist 104:501-528.

Lacerda A.E.B., Kanashiro M. and Sebbenn A.M. 2008. Effects of Reduced Impact Logging on genetic diversity and spatial genetic structure of a Hymenaea courbaril population in the Brazilian Amazon Forest. Forest Ecology and Management 255:1034-1043.

Lowe A.J., Boshier D., Ward M., Bacles C.F.E. and Navarro C. 2005. Genetic resource impacts of habitat loss and degradation; reconciling empirical evidence and predicted theory for neotropical trees. Heredity 95:255-273.

Magrach A., Guitián J., Larrinaga A.R. and Guitián J. 2011. Land- use and edge effects unbalance seed dispersal and predation interactions under habitat fragmentation. Ecological Research 26:851-861.

Medjibe V. and Hall J.S. 2002. Seed dispersal and its implications for silviculture of African mahogany (Entandrophragma spp.) in undisturbed forest in the Central African Republic. Forest Ecology and Management 170:249-257.

Medjibe V.P., Putz F.E., Starkey M.P., Ndouna A.A. and Memiaghe H.R. 2011. Impacts of selective logging on above-ground forest biomass in the Monts de Cristal in Gabon. Forest Ecology and Management 262:1799-1806.

Patiño V.F. 1997. Recursos genéticos de Swietenia y Cedrela en los Neotropicos: Propuestas para acciones coordinadas. Food and Agriculture Organization of the United Nations, Roma.

Plumptre A.J. 1995. The importance of "seed trees" for the natural regeneration of selectively logged tropical forest. Commonwealth Forestry Review 74:253-258.

Putz F.E. and Redford K.H. 2010. The Importance of defining 'forest': Tropical forest degradation, deforestation, long-term phase shifts, and further transitions. Biotropica 42:10-20.

Roberts J.T. and Heithaus E.R. 1986. Ants rearrange the vertebrate-generated seed shadow of a Neotropical fig tree. Ecology 67:1046-1051.

Santos J.V., Mas K.P., López C. and Snook L.K. 2005. El manejo forestal y la caoba en los ejidos de la zona maya, México. Desarrollo histórico, condiciones actuales y perspectivas. Recursos Naturales y Ambiente 44:27-36.

Schupp E.W., Jordano P. and Gómez J.M. 2010. Seed dispersal effectiveness revisited: a conceptual review. New Phytologist 188:333-353.

Sist P., Sheil D., Kartawinata K. and Priyadi H. 2003. Reducedimpact logging in Indonesian Borneo: some results confirming the need for new silvicultural prescriptions. Forest Ecology and Management 179:415-427.

Snook L.K. 2003. Regeneration, growth, and sustainability of mahogany in México's Yucatán forests. Big-Leaf Mahogany. In: Lugo A.E., Figueroa C.J.C. and Alayón M. Eds. Big-Leaf Mahogany: Genetics, Ecology, and Management, pp. 169-192, Springer-Verlag, New York.

Snook L.K. and Negreros-Castillo P. 2004. Regenerating mahogany (Swietenia macrophylla King) on clearings in Mexico's Maya forest: the effects of clearing method and cleaning on seedling survival and growth. Forest Ecology and Management 189:143-160.

Snook L.K., Cámara-Cabrales L. and Kelty M.J. 2005. Six years of fruit production by mahogany trees (Swietenia macrophylla King): patterns of variation and implications for sustainability. Forest Ecology and Management 206:221-235.

Sokal R.R. and Rohlf F.J. 1981. Biometry: The Principles and Practice of Statistics in Biological Research. W.H. Freeman and Company, New York.

Vander Wall S.B., Kuhn K.M. and Beck M.J. 2005. Seed removal, seed predation, and secondary dispersal. Ecology 86:801-806.

Wright S.J. and Muller-Landau H.C. 2006. The future of tropical forest species. Biotropica 38:287-301.

Received: September 26th, 2013

Accepted: February 5th, 2014 